プロラクチン受容体による乳腺機能の調節

一受容体遗伝子の構造一

酒井仙吉

東京大学農学部，東京都文京区 113

\title{
Regulation of Mammary Gland Function by Prolactin through Receptor Binding - Structure of Receptor Gene-
}

\author{
Senkiti SaKaI \\ Department of Animal Breeding, Faculty of Agriculture, \\ University of Tokyo, Bunkyo-ku, Tokyo 113
}

Key words : Prolactin, prolactin receptor, receptor gene, mammary gland, regulation

はじめに

牛乳は，良質の蛋白質を初めとして各種のミネラル， 特に消化吸叹され易いカルシュウム含み，栄養食品と いうよりは日常必須の食品の一っとなっている．牛乳の 需要は年々着実に增加してきた，将来においてもこの傾 向は変らない，現在の日本では罚用牛として約 200 万頭 飼育され，これらの牛が年間約 800 万トンの牛乳を生産 している.

牛乳は，ホルスタイン，ジャージーなど乳用に育種さ れたウシが生産する乳である. ウシの泌乳能力は，主に 「遭伝的改良」「飼鉒環境の改善」などにより飛躍的に 向上し，また，「機械による省力化」「経営の合理化」な ど著しい改善む計られてきた，しかし一方で，「酪農家 の高齢化，後継者不足」「牛肉輸入の自由化」「都市近郊 における経営の難しさ」など，酪農を取り巻く環境は益々 㛜しくなっている，地球規模で考えると様々な原因があ るにせよ全人類の $21 \%$ が極度の栄養不足状䔮であり， さらに加速度的に增加する傾向にある，わが国では発展 途上国と事情が多少異なるにしても食糧生産の重要性は 薄らぐことはない，ウシのミルク生産における優れた飼

日畜会報，63 (11)：1203-1208
料効率は，肉生産のそれ之比較すれば特筆するものがあ る.さらに，ウンはヒトが食糧に出来ない「草」を食べ， 人類が最も必要之する良質な蛋白質を生産する。

今後，多くの方面加ら生産性の向上に向けた様々な努 力がなされると考えられるが，家音育種学の見地からす れば遗伝的に優れた乳用牛の作出すその努力の一つであ る. 種雄牛の後代検定による選抜加行なわれている. そ れと同時に乳用雌牛の遺伝的泌乳能力を直接評価出来九 ば,その効果は計り知れない。

\section{1. 新しい選技指標の必要性}

現在飼育されている乳牛は，高度に選抜を繰り返され 缱伝的に相当程度均一であると予想され，従来から用い られてきたバラメーターによる選抜のみでは将来遺伝的 改良速度が徐々に低下してゅくであ万う。更に遗伝的な 改良を行なうとすれば，従来から用いられてきたパラォ ーター（乳量や乳質など）に加え，新しいパラメーター を導入する必要がある，従来應乳能力惊，主として是的 型質として报われてきたが，遺伝的改良の速度を考虑す ると質的型質として报うことが出来る遭伝的パラメータ 一を梌索することが重要である。そのパラメーターの発 
現には少数の迫伝子が関係し，かつ直接ミルクの合成に 倸わることが望ましい、また，ホルモン支配などその制 御機構が明らかであることが望ましい。

ブロラクチンは直接ミルク蛋白質の合成を調節し，プ ロラクチン受容体に結合してホルモン剌激を乳腺細胞に 伝える. 近年の研究からミルク合成能とプロラクチン受 容体数と関係することが明らかとなり，プロラクチン刺 激は受容体のレベルでも調節される，更に最す特筆すべ きことは, 泌乳量と受容体数と相関して変化することで ある。この観点からプロラクチン受容体は，葿伝的改良 のパラメーターとして，また，個体レベルで遗伝的泌乳 能力を知るパラメーターとして利用できる可能性がある。

詳しいプロラクチン受容体の性状之調節機構は既に本 誌で総説した ${ }^{23)}$. 第 $2 ， 3$ 章で主として育種のためのパ ラメーターとしての観点から簡単に説明する．個々の文 献については著者の総説にリストした，続いて第 4 章で 受容体遗伝子研究の現状を述べる。

\section{2. 乳腺機能を調節するホルモン}

ほしんどすべてのホルモンが值接的間接的にせよ乳腺 の増殖分化やミルクの合成に関与している，各々のホル モン作用むかなり詳しく調べられている. 中ですプロラ クチンはミルクの合成に密接に関係している，これらの 研究の大部分は実験動物を用いて明らかにされた。しい し，ウシやャギなど乳用家畜においてもミルク蛋白質の 合成はプロラクチンに依存している，培養した乳腺では カゼインの合成量はプロラクチン濃度に依存して変動す る.しかしながら，一般には泌乳中では血中プロラクチ ン濃度と泌乳量との間に余り明らかな関係が認められな い. 多分選抜の過程でプロラクチンが少なくて泌乳能力 が低いウシは淘汰され，現在飼育されているウシは十分 なプロラクチンレベルを保っているのであるう。すっと 屯，人為的にエルゴクリプチン処理などで血中のプロラ クチンレベルを極端に低下させると乳量す付随して減少 する．また，妊娠中では血液中にプロラクチンや胎盤性 ラクトーゲンが存在するにもかかわらず周知のようにミ ルクの合成は起らない，分娭後に起る本格的なミルクの 合成は，単にプロラクチンの増加のみでは説明できない。 これらの現象は，プロラクチンがプロラクチン受容体と 結合してホルモン情報を乳腺に伝えることを知机ば合理 的に説明できる、プロラクチン刺湤の強搦は，受容体レ ベルに依存しても変化する。

しかし，プロラクチンの重要性を否定するものではな く，今まであまり明らかでないプロラクチンの総分泌量 やクリアランス率の正確な測定，あるいはミルク中のプ
ロラクチンと泌乳能力との関係なども明らかとなれば, これらは遗伝的改良のパラメーターとなりうる。

\section{3. プロラクチン受容体数の変化}

ミルク合成能とプロラクチン受容体数は密接に関連し ている. 受容体は，細胞膜およびゴルジ膜など細胞内に も存在する. 全体としてみると妊娠中では受容体数は少 なく最屯多い必乳最盛期と比較すると $1 / 5$ 程度である。 分婏直前から增加が始まり泌乳最盛期で最大になり以後 末期に向加って徐々に減少する，末期では分婏直前と同 程度にまで減少する，妊娠中において人為的に受容体数 を增加させると泌乳が始まる，泌乳中では同一系統内で 泌乳量は受容体数上正の相関があるこ上，系統間では泌 乳能力の高い系統は受容体数わ多いこと，人為的に受容 体数を減少させると泌乳が停止すること，この状態で本 ルモン処理に上り受容体を增加させる上泌乳が回復する こと、などから直接的な関係が認められる。ウシなどの 乳用家畜では受容体の調節区子は明らかでないが，実験 動物では受容体は糖質コルチコイドにより調節されてい る. 後述するように受容体遺伝子はクローニングされて いる．この遗伝子を上り活発に発現させるか，発現の程 度の優れている個体を知ることが出来れば，これをパラ メーターとして産乳能力を改善できる可能性を示唆して いる.

基礎的研究がかなり進んだ現状に掞いても細胞内のプ ロラクチン受容体の存在意義（細胞膜より多く存在する） と，なぜ分子量が買なる二種類の受容体蛋白が存在する のか不明である．また，ポストレセブターのシグナル伝 達系む不明である。しかし，これら徐々に明らかにさ れようとしている。

\section{4. プロラクチン受容体遺伝子}

従来加らプロラクチン受容体の研究は，主に蛋白レベ ルで行なわれてきた，近年，その分子レベルでの解析が 進み遣伝子レベルでの研究も可能になってきた，受容体 のホルモンに上る調節，様々な生理的な条件下における 受容体の变動など，従来の研究で明らかになった結果上 同一であるが，遣伝子を用いて初めて可能になった研究 分野も多い，飛躍的に発展しているプロラクチン受容体 遺伝子研究の現状を紹介する。

(1) 遭伝子のクローニング

プロラクチン受容体は，分子量約 4 万と 8 万を持つ二 種類がある. 1988 年に分子量 4 万の受容体に対応する 遺伝子が最初にクローニングされだ2.ラットをエスト ロゲンで処理すると䀒プロラクチン受容体が堌加する。 
プロラクチン受容体による乳腺機能の調節

この組織から抗受容体抗体を結合したアフィニティカラ ムと SDS 電気泳動法を組み合せプロラクチン受容体が 精製された，それをトリプシンで限定消化し，プロティ ンシークエンサーにより部分的なアミ，酸配列が決定さ れた ${ }^{20)}$.このアミノ酸配列から予测される塩基配列を持 つ23 merのオリゴヌクレオチド（173〜180位アミノ 酸に相当) が合成され，されをプローブとして受容体遵 伝子の梌索が行なわれた、最終的に $1.5 \sim 1.8 \mathrm{~kb}$ (ノー ザンブロット，研究者により多少異なる）の受容体メッ センジャー RNA (mRNA) が同定され，そのcDNA がクローニングされたそその結果明らかになったことは, シグナルペプチッドとして 19 個のアミノ酸と受容体と して291 個のアミノ酸加成り立っていた，計算上の分 子量は 33,368 である. マウス肝では C 末端例に更に十 数個アミノ酸か結合した種も検出されている”，

次に同じプローブを用いて大きな分子量に対応する受 容体の遺伝子がウサ斗乳腺から得られた ${ }^{11}$. その mRNA の大きさは $2.2 \mathrm{~kb}$ (ノーザンブロット)であり, cDNA がクローニングされた，受容体として 592 個の アミ/酸（分子量の計算値 66,000）加ら成り立ってい る. 主な種類は上の一種類であるが，いずれの受容体に おいてもノーザンブロットで発現している mRNA.を 詳しく解析すると動物種あるいは陚器の違いにより多少 長さの異なる種も检出される。

いずれの受容体においても遗伝子の解析から予測され る分子量は，実際の蛋白筫の分子量より数干加的 1 万注 ど小さい，これは，蛋白質への翻訳後糖鎖の付加が起る ことに起因する，事実，プロテインシークエンサーの分 析結果で実際に受容体分子に䊰が結合していることが確 認されたここら二種類の受容体 cDNA の全塩基配列 は明らかにされている2,11)。後多くの動物種や臟器 で受容体遺伝子がクローニングされ塩基配列も明らかに されたが(後述)，大きな違いは報告されていない，

受容体は 1 本銷ペプチッドからなりサブュニットを持 たない，受容体分子は，細胞外，細胞膜貫通おょび細胞 内ドメインの 3 部分に大別できる。細胞外に出ている部 分（細胞外ドメイン）は，プロラクチンと結合する部位 を含む:いずれの受容体に扔いてもほぼ同一のアミノ酸 の配列であることから立体構造す似ていることが予測で きる.しかし，プロラクチンとの結合の強さは種あるい

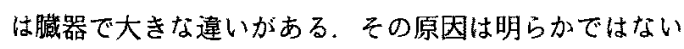
が，立体楧造（二次あるいは三次構造）あるいは楉鎖の 程度が異なることによるものと考えられる，膜を貫通し ている部分は疎水性のアミノ酸が連続している(アミ， 酸 211 がら 234 番目まで). 両者の受容体でアミノ酸配
列も同一である．細胞内ドメインはプロラクチンの情報 を伝える部位と考えられる、しかしながら峏受容体間で 細胞内ドメインは大きく異なり，特に大きな分子量の受 容体のアミ，酸配列加長い，両受容体の構造を模式図に 示した.

参考のため先にクローニングされたウサギ肝の成長木 ルモン受容体を示した ${ }^{182}$. 多少性筫が異なるが ${ }^{199}$ ，プロ ラクチンと成長ホルモンは同じジーンファミリーに属し， また, 両ホルモンは受容体レベルにおいても同一のジー ンフォミリーを形成する，近年細胞增殖を刺激するイン ターロイキンの受容体道伝子を含む，これらの受谷体遗 伝子はスーパージーンファミリーを形成すると考えられ ている ${ }^{1,13,21)}$.

\section{(2)、遺伝子の発現}

受容体遺伝子の発現は, 組織中の poly $\mathrm{A}(+) \mathrm{mRNA}$ のノーザンブロット分析で調へられている，受容体の存 在が良く知られている乳腺，肝裁を初めとして前立腺， 畉单，腎藏，小腸，副腎，精巢などでこの遗伝子が発現 している゙ 細胞やいくつかの培養細胞で娄発現が確認されてい る3.4. これらは、プロラクチンのバインデングアッセ 一の結果上も完全に一致している.プロラクチン受容体 には分子量の異なる二種類が存在する。しかし，その発 莧様式は臟器あるいは臓器内で異なる ${ }^{9}$ ，受容体を多く 含む肝臟と乳腺之で比較すると 2.14)，肝臟では妊娠中で 强く発現し，泌乳が始まると急激に発現が弱くなる。し かむ低分子量の受容体の mRNAの発現が顕著である. 高分子量の種の mRNA の発現はは之んど無く，また， 時期による発現量の変化屯ない，反対に，乳腺では妊娠 中の発現の程度は弱く泌乳が始まる之強く発現する. 同 じ乳腺で毛泌乳の初期では特に低分子量の種に対灾寸る mRNA が強く発現し, 泌乳中を通じ最す発現量が多い. 一方，高分子量のそれに対応する mRNA は泌乳の中 期までほぼ直線的に增加する。しかし，マウスにおいて は番，乳腺の結果のみが異なり，高分子量の受容体に対 する mRNA のみ発現し，をの発現量は娃娠や泌乳な ど時期による違いは少ない，幼若ラットにエストロゲン を投与すると肝臓で特に短い種の受容体遺伝子が発現す るが、乳腺では発現が起らない、しかし，上ト成長ホル モンやプロラクチンを投与するとラット肝においても高 分子量の受容体の遗伝子が発現する。この現象はラット 成長ホルモンの投与やオスでは認められない223，これら の結果は, 動物種や臓器が異なると受容体遭伝子の発現 制御機構る異なること，また，遺伝子の種類が異なると 発現樣式す異なることを示している。 
酒井

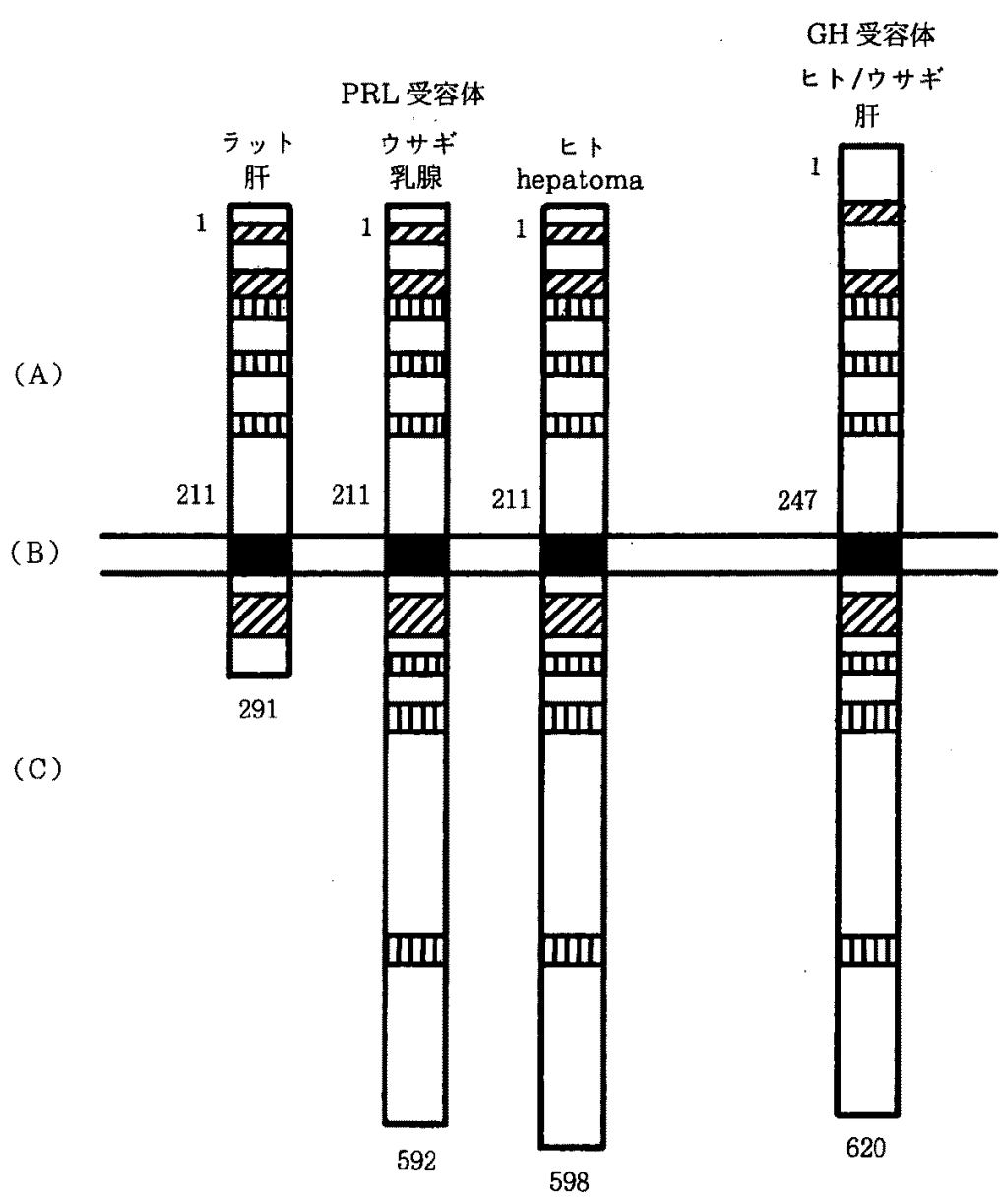

図 1. 各種プロラクチン（PRL）受容体と成長ホルモン（GH）受容体の比較 ウサギ/ヒト肝成長ホルモン受容体と比較し，70\%以上（斜線）及び $40 \sim 60 \%$ (綎線) 相同する部位. 番号は最初のアミ，酸，膜貫通の最初及び受容体の最後のアミノ酸を示す.

(A)：細胞外，（B）：膜貫通部位，（C）：細胞内

(3) 生理学的意義

クローン化した受容体遗伝子を培变細胞（transfection による)やアフリカッメガェルの卵 ${ }^{2}$ に導入（microinjectionによる) し発現させることが出来る。例えば CHO K1 細胞（ハムスタ一の莭巣由来の培養細胞でブ ロラクチン受容体の発現がなく，又，力ゼインを合成し ない）に短い種と長い種の受容体遭伝子が独立して導入 された ${ }^{16,17)}$ ，短い種の受容体はプロラクチンとの結合に 約 2 倍高い親和性を示した. $\beta$-ラクトグロブリンや $\beta-$ カゼイン遥伝子のプロモーターにクロランフェニコール アセチールトランスフェラーゼ（CAT）遺伝子を結合 し(キメラ逼伝子), 同時に導入 (co-transfection) することが出来る。なおこのキメラ蒚伝子は乳腺細胞に
導入するとプロラクチンに反応して CAT 遺伝子を活 性化する ${ }^{8}$. CHO K1 細胞にこれらの戛伝子が cotransfectionされた、プロラクキン存在下で培養し CAT アッセーを行なうと，長い種の受容体遺伝子を同 時に導入した場合にのみ CAT 遗伝子の発現か諗めら れ, 短い種の受容体遺伝子との組合せでは全く発現が認 められなかった，先に述べたように，泌乳開始から二種 類の受容体遺伝子の発現の様相は著しく異なり，長い種 の受容体遺伝子は徐々に增加する．マウスやラットでは この時期泌釈量は萣線的に增加する。これらの事実を考 え合せるとミルク蛋白質（カゼイン）合成の調節は主に 長い種の受容体が行なっているように考えられる。䀒臓 ではプロラクチン受容体が多いがカゼインを合成しない。 
肝䑏の受容体の大部分は分子量の小さい種である．著者 の最近の研究 (末発表) によれば比較的簡単に細胞膜あ るいは細胞内に存在する受容体を識别でき，泌乳中では それぞれ独立して変動する。泌乳量と相似して変化する 受容体は，主上して細胞膜に存在する。

受容体によるプロラクチンの二次刺潡伝達系（セカン ドメッンジャー) は解明されていない，ラットの卵巣 からクローニングされた長い種の cDNA を分析すると, 細胞内ドメインにチロシンリン酸化部位および ATP/ GTP の結合部位が存在すると言われたが28)，これを否 定する結果もある24)，今までのすべての報告は後者を支 持する. しかし，成長ホルモンはチロシンキナーゼを活 性化すること6.25)，乳腺であチロシンキ+ーゼインヒビ ター（genistein）はプロラクチンの作用を抑制するこ と吕，が報告されている．プロラクチン作用が乳腺之異 なるが，Nb2 細胞でプロラクチンの結合により細胞分 裂に関係する G-蛋白質がリン酸化される ${ }^{26,27}$ など，プ ロラクチンはリン酸化により細胞機能を調節している可 能性が指摘されている。

\section{おわりに}

泌乳能力の改善は適切な飼養管理や家畜管理の重要性 も忘れることが出来ないししかしあたて本総説ではプ ロラクチン受容体を指標とした乳用牛の効事的な選抜の 可能性を中心に述べた．プロラクチンはプロラクチン受 容体と結合して直接ミルク合成を調節するが，受容体は 従来選抜指標として用いられなかった，しかし，受容体 自身は筫的型質としての側面を持つことから乳用牛の育 璉において改良速度が速まるのではと期待できる.

乳牛という高価な経済動物を考慮すれば乳腺加ら細胞 膜を調製し，受容体数を測定することは非見㬰的である. ところが，脂肪球被膜は本質的に細胞膜に由来する。 ウ シやヤギなどの乳用家畜ではまだ報告は無いが，ウサギ で脂肪球被膜を用いて受容体が测定され，乳腺のそのレ ベル之良く相関する，孚用家畜においては，脂肪球被膜 を用いたアッセー法の確立が待たれる。

\section{References}

1) BAZAN, J.F., A novel family of growth factor receptors: A common binding domain in the growth hormone, prolactin, erythropoietin and $\mathrm{IL}-6$ receptors and the $\mathrm{p} 75$ IL-2 receptor $\beta$-chain. Biochem. Biophys. Res. Comm., 164 : 788-795. 1989.

2) Boutin, J-M., C. Jolicoeur, H. Okamura, J. Gagnon, M. Edery, M. Shirota, D.
Banville, I. Dusanter-Fourt, J. Duiane and P.A. KeLLy, Cloning and expression of the rat prolactin receptor, a member of the growth hormone/prolactin receptor gene family. Cel1, 53: 69-77. 1988.

3) Boutin, J-M., M. Edery, M. Shirota, C. Jolicoeur, L. Lesueur, S. Ali, D. Gould, J. DJIANE and P.A. KELLY, Identification of a cDNA encoding a long form of prolactin receptor in human hepatoma and breast cancer cells. Mol. Endocrinol., 3: 1455-1461. 1989.

4) BuCK, K., M. VANEK, B. Groner and R.K. BALL, Multiple forms of prolactin receptor messenger ribonucleic acid are specifically expressed and regulated in murine tissues and the mammary cell line HC 11. Endocrinology, 130 : 1108-1114. 1992.

5) Buczko, E., R. Zhang, C. Delgado and M.L. DUFAU, Heterogeneity of rat ovarian lactogen receptor species. Biochem. Biophys. Res. Comm., 165 : 921-928. 1989.

6) Carter-Su, C., J.R. Stubbart, X. Wang, S.E. STRED, L.S. ARGETSINGER and J.A. SCAFER, Phospholylation of highly purified growth hormone receptors by a growth hormone receptor-associated tyrosine kinase. J. Biol. Chem., $264:$ 18654-18661. 1989.

7) Davis, J.A. and D.I.H. Linzer, Expression of multiple forms of the prolactin receptor in mouse liver. Mol. Endocrinol., $3: 674-$ 680. 1989.

8) Doppler, W., B. Groner and R. Ball, Prolactin and glucocorticoid hormones synergistically induce expression of transfected rat $\beta$-casein gene promoter constructs in a mammary epithelial cell line. Endocrinology, 86 : 104-108. 1989.

9) Dusanter-Fourt, I., P. Gaye, L. Belair, B. Petridou, P.A. Kelly and J. Ditane, Prolactin receptor gene expression in the rabbit : identification, characterization and tissue distribution of several prolactin receptor messenger RNAs encoding a unique precursor. Mol. Cell. Endocrinol., 77: 181-192. 1991.

10) Dusanter-Fourt, I., L. Belair, C. Gespach and J. DJiAne, Expression of prolactin (PRL) receptor gene and PRL-binding sites in rabbit intestinal cells. Endocrinology 130 : 2877-2882. 1992.

11) Edery, M., C. Jolicoeur, C, Levi- 
Meyrueis, I. Dusanter-Fourt, B. Petridou, J-M. Boutin, L. Lesueur, P.A. Kelly and J. DJIANE, Identification and sequence analysis of a second form of prolactin receptor by molecular cloning of complementary DNA from rabbit mammary gland. Proc. Natl. Acad. Sci. USA, 86 : 2112-2116. 1989.

12) FAN, G. and J.A. Rillema, Effect of a tyrosine kinase inhibitor, genistein, on the actions of prolactin in cultured mouse mammary tissues. Mol. Cell. Endocrinol., $83: 51-55.1992$.

13) Goodwin, R.G., D. Friend, A.F. Ziegler, R. Jerzy, B.A. FALK, S. GIMPEL, D. Cosman, S.K. Dower, C.J. March, A.E. NAMEN and L.S. PARK, Cloning of the human and murine interleukin-7 receptors: demonstration of a soluble form and homology to a new receptor superfamily. Cell, 60 : 941-951. 1990.

14) JAHN, G.A., M. EDERy, L. Belatr, P.A. KeLLY and J. DJiAne, Prolactin receptor gene expression in rat mammary gland and liver during pregnancy and lactation. Endocrinology, 128 : 2976-2984. 1991.

15) Jolicoeur, C., J-M. Boutin, H. Okamura, S. Raguet, J. DJiane and P.A. Kelly, Multiple regulation of prolactin receptor gene expression in rat liver. Mol. Endo crinol., 3 : 895-900. 1989.

16) Lesueur, L., M. Edery, J. Paly, J. Clark, P.A. Kelly and J. DJIANe, Prolactin stimulates milk protein promoter in $\mathrm{CHO}$ cells cotransfected with prolactin receptor cDNA. Mol. Cell. Endocrinol, 71: R 7R 12. 1990.

17) Lesuevr, L., M. Edery, S. Ali, J. Paly, P.A. Kelly and J. DJiane, Comparison of long and short forms of the prolactin receptor on prolactin-induced milk protein gene transcription. Proc. Natl. Acad. Sci. USA, $88:$ 824-828. 1991.

18) Leung, D.W., S.A. Spencer, G. Cachianes, R.G. Hamond, C. Collins, W.J. Henzel, R. BARnard, M.J. Waters and W.I. WOOD, Growth hormone receptor and serum binding protein : purification, cloning and expression. Nature, 330 : 537-543. 1987.

19) Moldrup, A., N. Billestrup and J.H.
NiELSEN, Rat insulinoma cells express both a $115-\mathrm{kDa}$ growth hormone receptor and a $95-\mathrm{kDa}$ prolactin receptor structurally related to the hepatic receptors. J. Biol. Chem., $265:$ 8686-8690. 1990.

20) Oramura, H., S. Raguet, A Bell, J. Gagnon and P.A. KeLLL, Purification and protein sequence analysis of rat liver prolactin receptor. J. Biol. Chem., 264: 5904-5911. 1989.

21) Patthy, L., Homology of a domain of the growth hormone/prolactin receptor family with type III modules of fibronectin. Cell, 61: 13-14. 1990.

22) Robertson, J.A., L-A. Haldosen, T.J.J. WoOd, M.K. SteEd and J-Å. Gustafsson, Growth hormone pretranslationally regulates the sexually dimorphic expression of the prolactin receptor gene in rat liver. Mol. Endocrinol., 4 : 1235-1239. 1990.

23）酒井仙吉，乳腺ブロラクチンレセプター．日音会 報，61：469-480。 1990 。

24) Shirota, M., D. Banville, S. Ali, C. Jolicoeur, J-M. BOUtin, M. Edery, J. DJIANE and P.A. KeLLY, Expression of two forms of prolactin receptor in rat ovary and liver. Mol. Endocrinol., 4: 1136-1143. 1990.

25) Stred, S.E., J.R. Stubbart, L.S. ARgetsinger, W.C. Smith, J.A. Shafer, F. Talamantes and C. Carter-Su, Stimulation by growth hormone (GH) of $\mathrm{GH}$ receptor-associated tyrosine kinase activity. Endocrinology, 130: 1626-1636. 1992.

26) Too, C.K.L., P.R. Murphy and H.G. Friesen, G-proteins modulates proteinand interleukin-2-stimulated mitogenesis in rat $\mathrm{Nb} 2$ lymphoma cells. Endocrinology, 124 : 2185-2192. 1989.

27) Too, C.K.L., R.P.C. SHIU and H.G. FrIesen, Cross-linking of G-protein to the prolactin receptors in rat $\mathrm{Nb} 2$ lymphoma cells. Biochem. Biophys. Res. Comm., 173: 48-52. 1990.

28) Zhang, R., E. Buczko, C-H. TSAi-Morris, Z-Z. Hu and M.L. Dufau, Isolation and characterization of two novel rat ovarian lactogen receptor cDNA. Biochem. Biophys. Res. Comm., 168 : 415-422. 1990. 